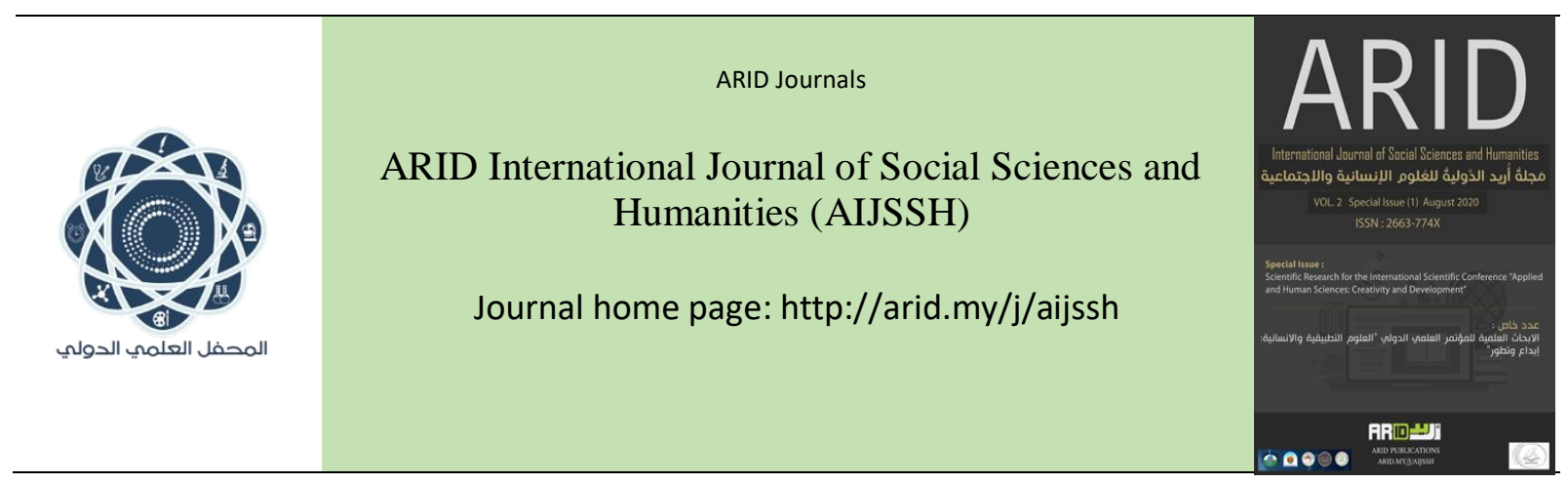

$$
\begin{aligned}
& \text { مَجلةُ أُريد الدَّوليةُ للعُلومِ الإنسانية والإجتماعية } \\
& \text { المجلد الثاني ،العدد الخاص ، آب } 2020 \text { م }
\end{aligned}
$$

\title{
Mechanism to combat money laundering in Iraqi banks through compliance monitor applications
}

\author{
آلية مكافحة غسل الأموال في المصارف العراقية من خلال تطبيقات مراقب الامتثال \\ الباحث يوسف كاظم كطان

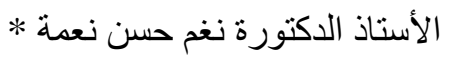 \\ كلية اقتصاديات الأعمال/جامعة النهرين
}

naghamalnama@gmail.com arid.my/0004-1771

https://doi.org/10.36772/arid.aijssh.2020.s.2125 


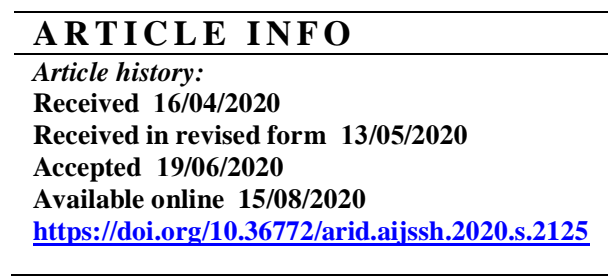

\begin{abstract}
The banking compliance function has become an important job in the banking sector, as it represents one of the internal banking supervisory bodies that tracks the extent of the bank's commitment (executive management، divisions، branches ... etc.) to implement laws، regulations, risks، regulations، and legislation. The extent of the bank's commitment to implement anti-money laundering procedures ، and the compliance monitor's follow-up in the bank to the extent of commitment to implementing these laws and legislation would limit and reduce money laundering operations L, and then avoiding the bank's exposure to sanctions of various kinds.
\end{abstract}




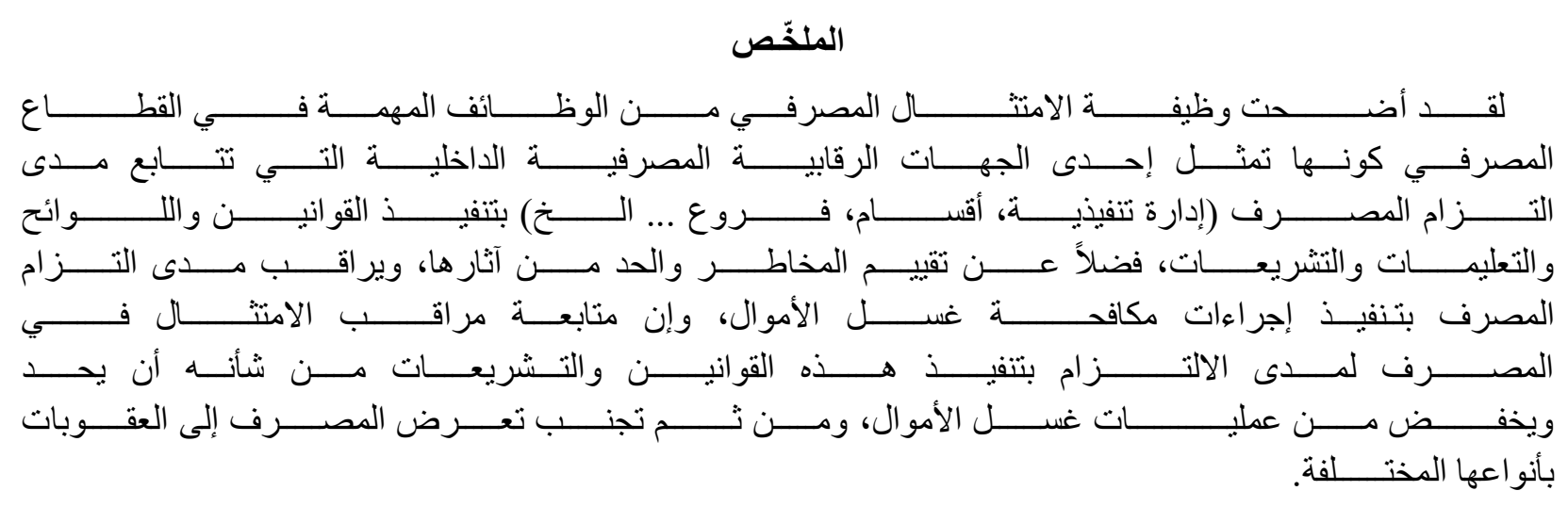


إن التطور الكبير في تكنولوجيا الاتصالات والمعلومات كان له أثر كبير في قطاع المصارف بشكل خاص وعلى القطاع المالي بشكل عام وعلى مدى السنوات السابقة، وأصبحت آداة بالغة الأهمية، توفّر فوائدا استراتيجية للمصارف ويحقق بواسطتها نوعية أفضل في الخدمات المصرفية، لكن التكنولوجيا المصرفية وتطبيقاتها المختلفة أمست اليوم تمثل تحديات وفرص في الوقت عينه للمصارف والجهات الرقابية والاشرافية للمؤسسات المالية، بذلك يجب على الجهات الرقابية في المصارف النظر في كيفية تحقيق التوازن بين التطوير والابتكار في القطاع المالي و المصرفي من جهة والحفاظ على سلامة ومتانة الجهاز المصرفي من جهة أخرى، ومن شأن هذه المقارنة المتوازنة تعزيز سلامة ومنانة المصارف وحماية المستهلك و الاستقرار المالي وتعزيز الامتثال للتشريعات والقوانين المعمول بها بما في ذلك قوانين مكافحة غسل الأمو ال دون الاضرار بالابتكار ات النافعة في الخدمات المالية، وبذلك يجب على القطاع المصرفي والمالي زيادة إجراءات التحقق والتدقيق في سبيل الحد من مخاطر هذه العمليات المالية المشبوهة والتي تخفي تحت طياتها عمليات غسل الأموال، وذلك عبر تفعيل دور مجمو عات الامتثال في مؤسساتها ولاسيما المصرفية منها، من خلال تحقيق إجراءات تنبيهية فاعلة تضعها في سلم أولوياتها،

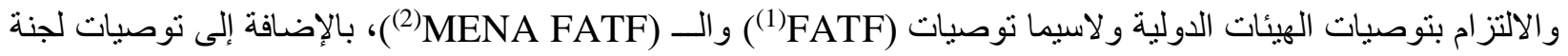
بازل وملحقاتها كقاعدة وركيزة أساسية لمكافحة ناجحة وفعالة لجرائم غسل الأموال، وذللك عبر الحد من مخاطر عدم الامتثال و تحفيز ها بالصلاحيات و الاستقلالية الواسعة الممنوحة إليها. مشكلة البحث:

إن زيادة عدد المصارف في العراق في مدة قصيرة، ودخول الاستثمار الاجنبي وكثرة الأموال المشتبه في مصادر ها إلى قطاع المصارف، أوجد الحاجة لترصين الرقابة المصرفية وإيجاد الحلول للانحر افات و السلبيات، والتي تمثلت في استحداث وظيفة مر اقبة الامتثال لمكافحة هذه الآثار و لاسيما عملية غسل الأموال، حيث تجلت المشكلة "في عدم إحاطة المشرع العراقي في موضوع مر اقبة الامتثال في المصارف بالكامل"، فتعليمات تسهيل تتفيذ قانون المصارف رقم ع 9 لسنة ع . . ب ذي الرقم

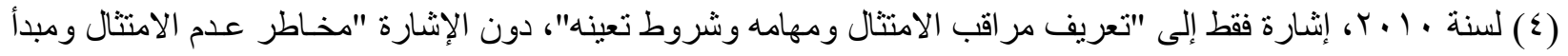
استقلالية مر اقب الامتثال من عدمه و علاقة مر اقبة الامتثال بغير ها من تشكيلات المصرف، ودوره في مكافحة غسل الأمو ال"

1 مجمو عة العمل المالي (FATF) مؤسسة حكومية دولية أنثئت في 1989 بواسطة الوزر اءو في الدول الاعضاء بها, تتمثل مهام مجمو عة العمل المالي

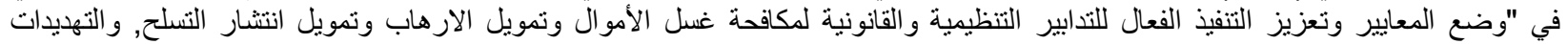

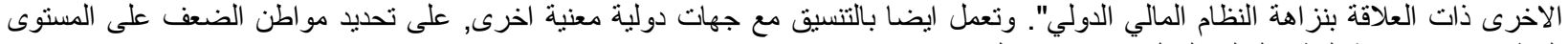
الوطني بهدف حماية النظام المالي الدولي من الاستغلال, (FATF, 2012, 7).

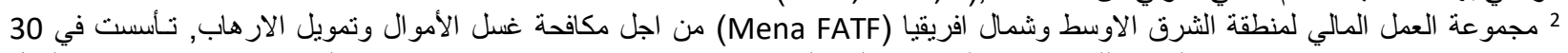

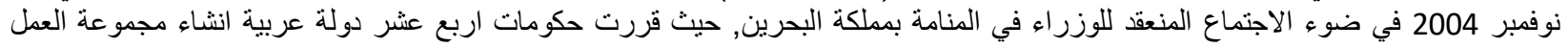

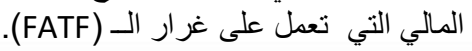




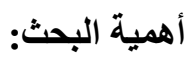

$$
\begin{aligned}
& \text { تبرز أهية البحث من خلال : ت ت } \\
& \text { 1. تناول أحد أهم محاور الرقابة في العمل المصرفي ألا وهو مراقب الامتثال. } \\
& \text { 2. أهمية مر اقب الامتثال المصرفي في تعزيز العمل المصرفي وتصحيح انحر افاته. } \\
& \text { 3. التعرف على وظيفة مر اقب الامتثال المصرفي وواجبات مر اقب الامتثال. } \\
& \text { 4. الأدوار المهمة التي يقدمها مر اقب الامتثال للحد من عمليات غسل الأمو ال. } \\
& \text { 5. بيان نشاط مر اقب الامتثال في مكافحة عمليات غسل الأموال }
\end{aligned}
$$

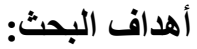

$$
\begin{aligned}
& \text { في ضوء مشكلة البحث و أهميته يحاول البحث إلى تحقيق مجموعة من الأهداف منها: } \\
& \text { 1. التعرف على مفهوم مر اقب الامتثال في المصارف العر اقية. } \\
& \text { 2. التعرف على مهام وظيفة مر اقب الامتثال المصرفي في المصارف العر اقية. } \\
& \text { 3. دور مر اقب الامتثال في نشاط مكافحة غسل الأموال. } \\
& \text { 4. تحديد المشاكل و المعوقات التي تو اجه مر اقب الامتنال. } \\
& \text { 5. بيان دور مر اقب الامتثال في نشاط مكافحة غسل الأمو ال في المصارف العر اقية. }
\end{aligned}
$$

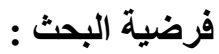

ينطلق البحث من فرضية مفادها أن "امتثال المصارف بالتعليمات والقو انين والأنظمة التي فرضها البنك المركزي وقانون مكافحة غسل الأموال وتمويل الإرهاب رقم 39 لسنة 2015 تؤدي إلى الحد من عمليات غسل الأمو ال في المصارف العر اقية"

$$
\text { أسلوب البحث: }
$$

يتم اتباع المنهج الوصفي التحليلي كونه أنسب منهج لاجراء الدراسات التي ترصد ظاهرة معينة لجمع الدلة والبيانات بهدف إيجاد تفسير علمي يرتبط بهذه الظاهرة. 


\section{المبحث الأول}

الاطار المفاهيم لمراقب الامتثال

أولا: مفهوم وظيفة مراقب الامتثال.

يعتبر القطاع المصرفي واحد من أهم الركائز الأساسية لعمل الاقتصاد لدى جميع الدول، وحتى تتم إدارة الأعمال المصرفية بطريقة سليمة وجيدة يجب أن تتم معاملاتها من بو اسطة الأطر الناظمة والسياسات و التعليمات والقواعد المطروحة، وتطبيق هذا المفهوم بشكل إيجابي من قبل إدارة المصرف مرتبط بتنفيذ الأعمال المصرفية بإدارة رصينة وقوة دور الأقسام الرقابية وقدرتها في ذللك على تحسين وتطوير الآداء، حيث إن توفير متطلبات الأقسام الرقابية ودعم وظيفة مر اقبة الامتثال بالثكل الصحيح و اعتبار ها من الدوائر الفعالة والرئيسية في المصرف وتوفير ما تستحقه من اهتمام من قبل إدارة المصرف سينعكس إيجابيا على الآداء العام للمصرف. [23] وفي ضوء ما تقدم تم استحداث وظيفة مراقب الامتنال في الهياكل التنظيمية للمصارف لغرض متابعة مدى التزام المصارف بالأنظمة والقو انين واللوائح التنظيمية والقو اعد المصرفية والتحوطية وتكليفه برفع تقارير دورية إلى مجلس إدارة المصرف ويطلع عليها مفتشو البنك المركزي العر اقي،[22] ومن خلال ذلك يمكن تعريف وظيفة مر اقب الامتثال بأنها "وظيفة مستقلة نهدف إلى التأكد من امتثال المصرف وسياساته الداخلية لجميع القو انين والتعليمات و الأوامر والأنظمة والمعايير وقو اعد السلوك والممارسات المصرفية الصحيحة التي تصدر من قبل الجهات الرقابية المحلية و الدولية التي تحدد وتقدم النصح والارشاد وتقيم وتر اقب وترفع التقارير إلى البنك المركزي ومجلس الإدارة حول مدى الامتثال

$$
\text { في المصرف". [36] }
$$

ثنانياً: مراقب الامتثال وصفاته.

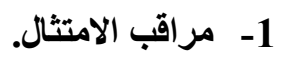

أوضحت الورقة الصادرة من لجنة بازل للامنثال ووظيفة مر اقب الامتثال في المصرف مر اقب الامتثال بأنها "وظيفة مستقلة تقوم بتحديد وتقييم وتقديم النصح و الإرشاد والمراقبة ورفع التقارير حول مخاطر عدم الامتنال في المصرف والتي تتضمن مخاطر عدم الامتنال للقو انين و التعليمات نتيجة لعدم الالتزام بالأنظمة وقو اعد السلوك و الممارسات السليمة المتبعة،[36] من

خلال التعريف أعلاه والخاص بلجنة بازل لمر اقبة الامتثال يمكن أن نستخلص مايلي:[7] ـ مراقب الامتنال هو قسم يتبع الهيكل التنظيمي في المصرف، دون أن يوضح فيما إذا كان هذا القسم يدار من قبل موظف (شخص) معين، أو على شكل وحدة قائمة تتكون بو اسطة مجموعة موظفين يترأسهم موظف (شخص) بطلق عليه مر اقب الامتثال في المصرف، ويبدو أن إدارة هذا القسم من قبل شخص محدد أو من قبل مجموعة موظفين يتر أسهم مر اقب الامتثال 
بعتمد على أمور عديدة، حجم المصرف وفيما إذا كان له فروع أم لا، فهذا يعكس مدى سعة الأنشطة المصرفية وسعة قاعدة المتعاملين مع المصرف ونوع الأنشطة المصرفية التي يقدمها المصرف، إضافة إلى موقع المصرف خاص (أهلي) أم حكومي. [40] ـ استقلالية قسم (وظيفة) الامتثال في المصرف، وهو المبدأ الخامس الذي أقرّته الورقة الصادرة من قبل لجنة بازل لعام 2005 حيث نصت على أنه "يتوجب أن يكون قسم (وظيفة) مر اقب امتثال ذات استقلال تام عن أنشطة وأقسام المصرف الأخرى"، فبتصورنا إن مبدأ الاستقلالية يعني أن مر اقب الامتثال يستطيع أن يعمل داخل المصرف دون أن يكون هنالك تدخل من قبل الإدارة أو تدخل خارجي في الأعمال التي وجدت لإنجازها، وهذا لا يتم فعلاً دون أن يكون لها وجود مستقل ضمن هيكل التظظيمي للمصرف.

\section{2- 2 - 2فات مراقب الامتثال}

أــ يتمتع مر اقب الامتثال بمسؤوليات إثر افية، الخبرة أو التعليم، ودرجة الحد الأدنى البكالوريوس أو (10) سنوات من الخبرة المصرفية والامتثال BSA. ويفضل أيضا أن يكون له تجربة قوية بالامتثال، ومهارات وقدر ات أخرى. ب- أن تكون لايه معرفة و اسعة بالقو انين و اللوائح المصرفية الاتحادية. ج- له القدرة على تفسير القو انين في سياسات وإجراءات لدعم وتعزيز نمو المؤسسات المالية مع الحفاظ على التقيمات التتظيمية المعلنة. دـ أن يمتلك مر اقب الامتنال القدرة على كيفية حل المشكلات العملية والتعامل مع مجموعة متنوعة من المتغير ات الملموسة. هـ أن يكون من ذوي المؤ هلات و الخبرات و الدرجات العليا في السلم الوظيفي و السيرة الحسنة. [31]

\section{ثانياً: شروط ومهام مراقب الامتثال في المصارف. 1- - 1 - شروط مراقب الامتثال في المصارف}

لا يتم اختيار شخص يدير وظيفة مراقبة الامتثال في المصارف ما لم تتوفر فيه شروط معينة، تتيح له القدرة على إدارة الوظيفة المسؤول عنها. أما فيما يخص الورقة التي صدرت من لجنة بازل للامتثال ووظيفة الامتثال لسنة 2005، نجد أن المبدأ الــ(8) منها نص على أنه "يجبأن تتاح في الأشخاص الذين تقع على عاتقهم تتفيذ مسؤوليات الوظيفة الخبرة والتأهيل بعض المهنية والثخصية التي تساعدهم في تتفيذ واجباتهم بكفاءة عالية". وييدو أن هذا المبدأ قد أصرّ على أن تتوفر بعض السمات الثخصية والمهنية في كافة موظفي مر اقبة الامتثال بغض النظر عن كونه هو الثخص الذي يسأل عن مراقبة الامتثال أو الموظفين العاملين معه. لقد نصت التعليمات على أنه "يجب أن يتوفر في الأشخاص الذين يديرون مسؤوليات وظيفة مر اقب الامتثال الآتي: [15] 
1. حتى يتمكن من تنفيذ الواجبات الموكلة إليه بكفاءة عالية يجب أن تتوفر لديهم المؤهلات والخبرة والصفات المهنية و الثخصبة.

2. القدرة على التفسير و الفهم الصحيح و السليم للقو انين و الأنظمة والمعايير الواجب على المصرف الامتثال لها وتأثثرات ذلك على المصرف.

3. ملم بكافة التطورات التي تحصل على الأنظمة والقو انين والمعايير الواجب على المصرف الامتثال لها عن طريق التعلم

$$
\text { 2- مهام مراقب الامتثال. }
$$

من الضروري تحديد مهام ومسؤولية مر اقب الامتثال ولابد للإدارة العليا في المصرف أن توضح ذلك بشكل كامل ومكتوب، إضافة إلى توضيح العلاقة بين مر اقب الامتثال و الإدارة العليا والإدارات المختلفة في المصرف، كما أوضحت الفقرة ثانيا من المادة (71) من تعليمات تسهي تنفيذ قانون المصارف العر اقي مهام مر اقب الامتثال بالآتي: [38] 1. إن المسؤولية في مدى التزام المصرف بقرارات مجلس الإدارة والسياسات والإجراءات الداخلية، إضافة إلى الإجراءات التي صدرت بموجب القو انين والتعليمات التي من البنك المركزي العراقي تقع على عاتق مراقب الامتثال في المصرف، ويجب أن يحضر مر اقب الامتثال اجتماعات مجلس إدارة المصرف بمهمة مر اقب امتثال. 2. يجب أن يتوفر في مر اقب الامتثال إطلاع وتفهم متكامل للتعليمات والقو انين التي يتصدر من قبل البنك المركزي و القو انين و التعليمات ذات العلاقة غير المباثرة و لا يشترط أن يكون قانونيا. 3. أن يكون ذات معرفة وإطلاع بكافة الخدمات التي يقدمها قطاع المصارف والتي تتسجم مع المتطلبات المتطورة في الاقتصاد العر اقي. 4. على مر اقب الامتنال أن يتعرف على القو انين والتعليمات و الأنظمة المتخصصة بالنشاط المصرفي والتي من الممكن أن يشمل ذلك منطلبات ليس لها علاقة مباشرة بالأنشطة المصرفية وبعض العمليات المصرفية، كما يمكن للقسم القانوني في المصرف أن يقوم بتقديم المساعدة إلى قسم الامتنال في هذه المهمة. 5. مر اجعة قرار ات الإدارة العليا وكذلك السياسات والإجر اءات التي لها علاقة بنشاط المصرف وتتخيص مدى ترابطها مع القو انين و التعليمات و اللوائح التنظيمية المتخصصة وتقديم أي ملاحظات فيها. 6. تحديث السياسات و الإجراءات السابقة للعمليات المصرفية بناء على منطلبات تطور النشاط المصرفي أو اقتر اح السياسات و الإجر اءات اللازمة للعمليات الجديدة، وعلاقات المصرف و إقرار ها من مجلس الإدارة في المصرف. [21] 
7. مر اجعة الإجر اءات التي تنفذها الإدار ات المختلفة في المصرف والتأكد من أنها منسجمة مع الأنظمة والقو انين المختصة

$$
\text { وتقويم مدى ملائمة الإجر اءات والتوجيهات الداخلية، وتقديم الاقتر احات لمعالجة الانحر افات إن وجدت. }
$$

8. رفع تقارير شهرية إلى الإدارة العليا وفصلية إلى المديرية العامة لمراقبة الائتمان والصيرفة في البنك المركزي تتناول الانحر افات التي نم اكتشافها مع تقديم الاقتر احات والإجر اءات المطلوبة للتصحيح حتى لا يتم تكرار ها في المستقبل، وأن يحتفظ مر اقب الامتثال بنسخ من تلك التقارير في الملفات الخاصة وتكون خاضعة إلى تفتيش البنك المركزي. 9. اقتراح بعض الدورات التدريبية على السياسات الموضوعة و الإجراءات التي يجب أن تنفذ، والتأكيد على ضرورة أن يلتزم بها من قبل الموظفين الموجودين بشكل عام و الموظفين الجدد بشكل خاص. 10. إعداد جدول بالمنتجات والخدمات المصرفية ومجالات العمل التي تساعد في تحديد مجالات العمل جميعها التي لم يتم تغطيتها في الماضي وبالتعاون مع بقية الإدار ات.

11. تنظيم النشاطات المصرفية والخدمات بما يقابلها من متطلبات قانونية وتعليمات مرتبطة بها ومن الممكن إتمام ذلك بواسطة تحديد القانون الذي يستوجب تطبيقه وبعد ذلك وضع الأعمال والخدمات المصرفية التي تنطوي تحتها. [14] ثالثاً: المؤهلات المطلوبة لمراقب الامتثال. إن مر اقب الامتثال هو الثخص المسؤول عن متابعة الالتزام بالإجر اءات و السباسات المقرة بموجب القوانين و اللوائح التنظيمية التي يصدر ها البنك المركزي وقرارات مجلس إدارة المصرف، ولذلك لابد من أن تنطبق مؤهلاته مع المواصفات التي نص عليها قانون المصارف التي ذكرت في الأساس القانوني لهذه التعليمات.

$$
\text { 1-2-5-1 مؤ هلات مر اقب الامتثال. }
$$

يكون تعيين مر اقب الامتثال وفق الفقرة الثالثة من المادة (18) من قانون المصارف رقم (94) لسنة 2004، من قبل مجلس إدارة المصرف على أن تتوفر في هذا الشخص الثروط التالية: [25]

$$
\text { أ- أن يكون شخص صلالح و لائق ولديه أهلية قانونية. }
$$

بـ - أن يملك الخبرة و الكفاءة المصرفية التي يطلبها عمل مر اقب الامتثال وفق العمليات المصرفية. ج- أن لا يكون موظفا في مصرف ثاني أو اداري تابع إلى مصرف آخر ، أو حتى مديرًا مفوضاً لمصرف آخر. د- أن يكون متفر غا لهذه المهمة ومقيم في داخل البلد. [21] لذا ينبخي أن تتو افر في الثخص الذي يكلف بمهام مسؤولية مر اقب الامتثال وكحد أقل المؤهـلات الآتية: 1. بمتلك شهادة جامعية أو ذات علاقة مهنية عالية. 2. يملك خبرة كافية في العمل المصرفي في المجالات جميعا (لا تقل عن 10 سنوات)، 


$$
\begin{aligned}
& \text { 3. المعرفة التامة بجميع الأنظمة المصرفية و التعليمات و الأنظمة ذات العلاقة. } \\
& \text { 4. إتقان اللغة العربية و اللغة الانكليزية. } \\
& \text { 5. لديه خبرة في الإشر اف الإداري و التدقيق ومجالات الرقابة. } \\
& \text { 6. إمام جيد بآليات مكافحة غسل الأموال وتمويل الإرهاب. [38] } \\
& \text { رابعاً: الوصف الوظيفي لمرقب الامتثال. }
\end{aligned}
$$

من الضروري أن يتم وضع وصف وظيفي متكامل ومكتوب لمر اقب الامتثال في المصرف على أن يتضمن:

$$
\text { توضيح المسؤوليات العامة لمجالات العمل و الخدمات المصرفية والمنتجات التي تشتمل عليها. }
$$

1. وضع قائمة بالأعمال التي سيقوم بها مر اقب الامتنال من أجل تأدية عمله، بتعليمات تصدر لاحقا.

$$
\text { 2. المساعدة على حل المشاكل ومتابعة الأعمال التصحيحية وتدريب العاملين. }
$$

3. تحديد صلاحياته و علاقته بالدو ائر الأخرى للمصرف ويفضل أن يكون بمسنوى معاون مدير عام أو معاون مدير مفوض

$$
\text { أو خبير، ويشترك في اجتماع مجلس الإدارة بصفته مر اقب. [21] }
$$

4. العمل مع المفتشين و المدققين للمساعدة في تطوير وسائل السيطرة المناسبة لتجنب المشاكل في المستقبل. حتى يكون مر اقب الامتثال أكثر فاعلية فأنه يحتاج إلى مصادر مختلفة لمعلوماته، وأهم هذه المصادر هو المكتبة التي يقوم بإنشائها و التي يجب أن تكون قد احتوت على معلومات منكاملة حول اللوائح التنظيمية والقوانين والمنتجات المصرفية التي يكون مراقب الامتثال مسؤو لا عنها. وفي نفس الوقت، ولا يقلل ذلك أهمية عن المكتبة، تكوين علاقات عمل متينة داخل المصرف ويفضل أن يكون ذلك عن طريق تكوين لجنة مر اقبة الامنثال تكون برئاسة مر اقب الامتثال. [39] و هذه العمليات

$$
\text { سوف تساعد في اتجاهين: }
$$

$$
\text { 1. الحصول عل قنوات مختلفة لمصادر المعلومات اللازمة. }
$$

2. تكوين نو اة يستطيع أعضاؤ ها من تحديد المشاكل و المو اضيع من أجل حلها والمقترحات المتعلقة في تتفيذ اللوائح التنظيمية

$$
\text { ومدى التأثثر على عمل المصرف وتكون الر أي المناسب لنقلها إلى الجهات التي أصدرتها. }
$$

\section{غسل الأموال وطرق المكافحة}

لقد بدأت الجهود لمكافحة عمليـات غسل الأمو ال منذ سنـوات من الزمن وذلك بإصدار تشريعات جديدة أو تعديل التشريعات الحالية وذللك على المستوى المحلي و الدولي، وتتبع أهمية هذا الموضوع نتيجة للأثار السلبية الناجمة عن عمليات غسل الأموال وتز ايد حجم هذه العمليات إذ من المنوقع أن يبلغ حجم عمليات غسل الأموال المتوقعة (1.4) تريليون دولار. [17] وفي هذا 
السياق قام البنك المركزي العر اقي بإصدار جملة من الضوابط الرقابية التي تخص مكافحة غسل الأموال وذلك من خلال إحكام قانون مكافحة غسل الأموال رقم(39) لسنة 2015، وما جاء به من التزامات على المصارف و أولها المصارف العاملة في العراق و الفروع التابعة لها في خارج البلد وفروع المصارف الاجنبية العاملة في العراق، وقد نم الأخذ بنظر الاعتبار عند إصدار هذه الضوابط الرقابية المستجدات العالمية بشأن مكافحة غسل الأموال بعد تحديث التوصيات الأربعين بشأن مكافحة غسل الأموال الصادرة من مجموعة العمل المالي FATF، معتبرة هذه التوصيات بمثابة معايير دولية في مجال مكافحة هذه الظاهرة، كما تطبق هذه الضو ابط على كافة الفروع التي تعمل بالخارج للمصارف العاملة في العراق مع مر اعاة أنه في حالة عدم تثابه الالتزامات المذكورة بهذه الضوابط عن تلك التي تفرضها الدولة المضيفة للفروع العاملة، تم تطبيق الالتز امات الأشد بما لا يختلف مع التعليمات الرقابية أو التشريعات المطبقة بالدولة المضيفة، مع مر اعاة إبلاغ البنك المركزي العراقي، أما في عدم المقدرة على تطبيق تدابير سليمة لمكافحة غسل الأموال نتيجة لتلك التعليمات أو التشريعات، وإن الهدف من هذه الضوابط

$$
\text { يمكن حصره بما يلي: }
$$

1. تهدف هذه الضو ابط إلى التأكد من امتثال المصارف بالتقيد بأحكام "قانون مكافحة غسل الأمو ال" رقم (39) لسنة 2015. 2. حماية القطاع المصرفي من عمليات غسل الأموال، وذللك من خلال امتثال المصارف بتطبيق السياسات والأنظمة و الإجراءات والضو ابط واللوائح والمبادئ التي تكفل منع واكتشاف أنشطة غسل الأموال والتبليغ عنها طبقا للمعايير الدولية. 3. حماية المصارف من العمليات غير القانونية، ومنع استغلالها كقنوات لتمرير العمليات والمعاملات غير المشروعة التي قد تنطوي على غسل الأموال و أي أنشطة غير مشرو عة أخرى. 4. تعزيز سلامة القطاع المصرفي وحماية سمعته ونز اهته بما يكفل حماية عملائه. ويترتب على مخالفة الضوابط التي يصدرها البنك المركزي للمصارف بما فيها تعليمات مكافحة غسل الأموال إيقاع عقوبة أو اكثر بحق المصرف المخالف، وهذه العقوبات تعطي للضوابط قوة إلزام من حيث تطبيقها، مؤيدة بإجراءات أو جزاءات أقلها التنبيه، وأثدها إلغاء الترخيص، على أن هذه العقوبات تخضع لرقابة القضاء. [3] أولاً: مفهوم غسل الأموال: غسل الأمو ال: مصطلح يعرف باللغة الإنكليزية (Money Laundering) وترجم إلى اللغة العربية بعدة مصطلحات منها، تييض الأموال الملوثة، أو الأموال السود أو تنظيف الأموال القذرة أو الاستثمار ات الكاذبة، أو تطهير العملة. [30] كلها تدل بالمعنى عينه، إلا أنَّ الترجمة الحرفية للمصطلح هو غسل الأموال التي طبق بها الولايات المتحدة في وثائقها،[18]وهو الأكثر شيوعا وقبولا على نطاق واسع في الاستخدام الثعبي في جميع أنحاء العالم. [42] ويرتبط مصطلح غسل الأموال 
بعصابات الجريمة المنظمة من حيث المصدر، حيث ان هذه العصابات تمنلك امو الا كبيرة عن عمليات محرمة مثل المخدرات و القمار وبذلك فأن هذه الجريمة لا تقتصر على مرتكبيها فقط، و إنما تتعداها إلى كل من يشارك فيها، من مساهمين ومستفيدين وكل من أنكر حقائق تتعلق بطبيعة المصدر أو بعلاقة الملكية. [19] حيث سميت هذه العملية (غسل الأموال) تشبها بحالة مماثلة ظهرت في نهاية عقد الثناثثينات من القرن العثرين، [11] والمتمثلة بتكنولوجيا جديدة خاصة بأجهزة غسل الملابس الأتوماتيكية وتزامن هذا الظهور مع تللك الظاهرة فانسحب استخدام هذا المصطلح في تلك المدة، [6]ويمكن تعرف غسل الأموال على أنه العملية التي يتم بو اسطتها ضخ الأرباح الناتجة عن العمليات ذات النشاط الإجرامي والأنشطة غير المشرعة داخل النظام المالي العالمي بشكل سليم بحيث يصعب التعرف على المصادر الأصلية لهذه الأموال، ومن ثم يمكن انفاقها واستخدامها في استثمار ات لأغر اض مشرو عة. [9] ثنانياً: مراحل غسل الأموال. قبل الخوض في تفصيل المراحل التي تمر منها عملية غسل الأموال، لابد من الإشارة أن هذه العمليات ليس من السهل إنجاز ها بالنظر إلى حجم السيولة النقدية محل الغسل، ثم بالنظر إلى تحويل ونقل هذه الأموال من بلد إلى آخر، بالسر عة المطلوبة وبالأساليب المناسبة. [1] ولكي تأخذ عملية غسيل الأمو ال طريقها دون أي إجر اء قانوني، ومن ثم تصبح كأنها تلك الأموال ذات مصادر مشروعة وجزء من المال في المجتمع، لابد أن تمر بمر احل عديدة. ويلاحظ أن أكثر الأدبيات المتخصصة والأبحاث والدراسات التي تناولت هذه الظاهرة تثير إلى أن هنالك ثلاث مراحل تمر بها عملية غسيل الأموال أو التي يعتمدها غاسلو الأموال لكي يصلوا لأهدافهم، [29]وهي كالآتي:

1- مرحلة الإيداع: وهي التي يبدأ فيها غاسل الأموال بالتخلص من الأموال القذرة (غير المشروعة) المتحصل عليها من الجر ائم الأصلية، (الخريشة، 2009: 38). حيث يتم ذلك أما بإيداعها داخل النظام المالي المصرفي أو تحويلها خارج الدولــة التـي يتم فيها العمل أو الأعمـال غير المشـروعـة،37] كما تعتبر هذه المرحلة من أصعب المراحل لاحتمالية انكثاف مصدر هذه الأموال وخلالها يقوم مرتكبو الجرائم الذين اكتسبوا عنها أموالا بمحاولة إدخالها إلى النظام المالي والمصرفي الرسمي و غالبا تكون في نفس مكان وقوع الجريمة. [7]

كما أن هذه المرحلة من أفضل المراحل للكثف عن غاسلي الأموال، حيث تعتبر نقطة الضعف الأساسية في إجر اءات غسل الأموال، وذللك لأن غاسلي الأموال تتوفر لهم أموالا سائلة وبكمبات كبيرة جداً، حيث يعمدون إلى تجزئتها إلى عدة أجزاء صغيرة لأبعاد الثبهة عن هذه الأموال عند ادخالها في النظام المصرفي وبذلك يتم درء التساؤلات التي تطرحها الأجهزة الرقابية في المصارف،[20] لذلك تعد مرحلة التوظيف أضعف حلقات غسل الأمو ال مقارنة مع المر احل التالية: [13] 
2- مرحلة التمويه أو التغطية: في هذه المرحلة يتم تبادل ونقل الأموال الغير مشروعة ضمن النظسام المصرفي الـذي تم إدخالها فيه، [2] وتهدف إلى عزل الأموال غير الشرعية عن أصلها بإحداث مجموعة معقدة ومتعددة من العمليات المصرفية المصممة للتضليل، ما يعني تطبيق آلية في هذه المرحلة يصعب معها كثف الأمو ال الحقبقية لتبق الأمو ال بدون مصدر . [24] وفي هذه المرحلة يتم إخفاء أو فصل الأموال غير المشروعة من مصدر ها الأصلي وذلك عبر سلسلة من العمليات المالية الثر عية ويلاحظ إن مرحلة التمويه أصعب مرحلة الابداع بالنسبة لجهات مكافحة غسل الأموال، [18] وتتميز مرحلة التمويه بأنها أصعب من سابقتها حيث من الصعب يصبح كثف حقيقة الأموال غير المشروعة، وذلك لكثرة الصفقات المالية وتعددها، و التي تتداخل مع بعضها البعض فتجعل هناك مهمة صعبة في تتبع الدخل غير المشروع، [26] و هذه المرحلة نرجع أهميتها وخطورتها في استخدام أساليب تكون مرتبطة بالطبيعة الدولية، فمعظم وقائعها تتم وتجري في عدة دول، ولها من الأساليب المتنو عة ما يصعب التوصل إليها بسهولة. [5] 3- مرحلة الدمج: من خلالها يتم دمج الأموال واختلاطها في النظام المصرفي بالأمو ال المشروعة، [10] بحيث تصبح كأنها أمو ال مشرو عة تماما أو ناتجة عن أنثطة اقتصادية مقبولة ومن ثم تكتسب هذه الأمو ال صفة قانونية وتدور في نشاط الاقتصاد الوطني. [43] ومنها يصبح أمر اكتشاف جريمة غسل الأموال والجريمة الأصلية التي نتجت عنها أمرا صعبا للغاية بل مستحيلا، نظر الصعوبة فصل المال المشروع عن المال غير المشروع. وخلاصة القول هو بإمكاننا أن نقول بأن مراحل غسل الأموال المتقدمة هي في الحقيقة عملية واحدة تشمل ثلاثة أنواع من النشاطات المتصلة والمترابطة بدلاً من أن نجعلها ثلاث مراحل متميزة ومنفصلة، وفي سياق ما تقدم يمكن أن تنزامن هذه المر احل فيما بينها، بعضها أو كلها بحسب الظروف العامة للأطراف المعنية، ومن الممكن أيضا في بعض الأحوال تخطى مرحلة أو أكثر ، أو انتهاج طرقاً جديدة تماماً بغسل الأموال غير المشروعة. [5] ثالثاً: الامتثال في المصارف ودوره في حمايتها أوجبت التوصية (18) من نوصيات مجموعة العمل المالي تعيين موظف مختص بالامتثال على مستوى الإدارة من كل مصرف، إذ يساعد مثل هذا الموظف على ضمان تكريس إدارة المؤسسة لجهودها لتطبيق الامتنال. [40] كما أكد المشرع العر اقي على إضافة وظيفة رقابية داخلية عن طريق "قانون المصارف العراقي" رقم (94) لسنة 2004 في الفقرة (3) من المادة (18) منه، و هي مر اقب الامتثال، ونم تطبيق هذه الوظيفة فعلاً في عام 2006. ويكون مر اقب الامتثال مسؤولاً عن التحقق من الالتزام ببرنامج مكافحة غسل الأموال وتعديله إن تطلب الأمر ذللك، كذلك الإلمام بالتطورات القانونية

و النظامية في هذا المجال. [34] 
هذا وتقع على كاهل مسؤول مراقبة الامتثال تكوين برنامج وتعميم تعليمات وتدريب العاملين وكافة الأقسام بمختلف المستويات الإدارية المختلفة لكافة المضامين المرتبطة بغسل الأموال والإطلاع على جميع التطورات القانونية والتنظيمية

المتعلقة بذلك ويتلخص دور مسؤول مراقبة الامتثال في مكافحة غسل الأموال بما يلي: [16] 1. أعداد سياسة اعرف عميلك (KYC) و السياسات الخاصة بمكافحة غسل الأمو ال. 2. مر اقبة كافة العمليات النقدية والاستثمارية والحوالات و المعاملات الائتمانية. 3. ان يتابع مر اقب الامتثال القائمة السوداء التي تخص المشبو هين عالميا وما يطر أ عليها من تعديلات. 4. من خلال آلية إعرف عميلك (KYC) يتم الإبلاغ عن الحالات المشبوهه إلى وحدة مكافحة غسل الأموال في البنك المركزي. 5. تقسيم عملاء المصرف إلى عملاء ذوي مخاطر ( منخفضة، متوسطة، مرتفعة ) و الاستمر ار بمتابعة ومر اقبة العملاء ذات المخاطر المنخفضة ومتوسطة مخاطر ها وايقاف التعامل مع العملاء ذات المخاطر المرتفعة. [28] 6. التأكد من أن جميع العاملين بالمصرف ملتزمين من تطبيق سياسة إعرف عميلك (KYC) وسياسة مكافحة غسل الأموال. 7. أن يقدم دورات تدريبية وورش عمل المتعلقة بغسل الأمو ال والمكافحة لكافة العاملين وبمختلف المستويات. 8. الإلمام التام و الكامل بجميع التعليمات و القو انين المختصة بمكافحة غسل الأموال سو اء تلك التي تصدر من داخل أو الدولية وأية تعديلات تطر أ عليها.

9. رفع تقارير أو توصيات إلى مجلس الإدارة و الإدارة التنفيذية حول كافة العمليات التي تتضمن اشتباها. 10. الاحتفاظ بجميع البيانات و السجلات و المعلومات التي تخص كافة العمليات المشبوهة وغير العادية والتي تم الإبلاغ عنها سابقا من خلال التقارير وحفظها لمدة لا تقل عن 5 سنوات. [40] رابعاً: نشاط مراقب الامتثال في مكافحة غسل الأموال. يقوم مر اقب الامثتال في مجال مكافحة غسل الأموال بمهام عدة حددتها المادة (4) من الفصل الثالث من الضوابط الرقابية للمؤسسات المالية المصرفية وغير المصرفية بخصوص مكافحة غسل الأموال الصادرة في (2016/9/19)، [27] و التي جاء فيها "يتعين على مراقب الامتثال أن يعد تقرير دوري مرة على الأقل كل ثلاثة أثهر عن نشاط مكافحة غسل الأموال، و إرسال هذا التقرير إلى هذا البنك مشفوعا بملاحظات وقرارات مجلس إدارة المؤسسة المالية. ويتضمن هذا التقرير كحد أدنى ما يأتي: 1. الجهود التي تمت خلال فترة إعداد التقرير بشأن العمليات غير العادية والمشتبه بها، وما اتخذ في شأنها. 
2. ما تسفر عنه المراجعة المستمرة لنظم وإجراءات مكافحة غسل الأموال المتبعة بالمؤسسة من نقاط ضعف ومقترحات تجنبها، بما في ذلك التقارير التي تتيحها الأنظمة الداخلية بالمؤسسة المالية عن العمليات المشتبهة بها. 3. ما نم إخخاله من تعديلات على السياسات أو النظم الداخلية أو الإجراءات بالمؤسسة المالية في شأن مكافحة غسل الأموال

$$
\text { خلال المدة التي تم من خلالها التقرير. [27] }
$$

4. توضيح مدى الإلتزام بتطبيق الخطط الموضوعة خلال فترة إعداد التقرير للإشراف العام ميدانياً ومكتبياً على مختلف فروع المؤسسة المالية للتحقق من النز امها بتنفيذ أحكام القو انين و الضوابط الرقابية والنظم الداخلية في شأن مكافحة غسل

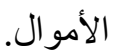

5. بيان الخطة الموضو عة للإشر اف العام مكتبيا وميدانيا على كافة فروع المؤسسة المالية خلال الفترة التالية للتقرير. 6. توضيح شامل بالبر امج التدرييية والورش التي تم عقدها للعاملين بالمؤسسة المالية في مجال مكافحة غسل الأموال خلال الفترة التي يغطيها التقرير.

7.

8. نتائج مر اجعته لأنظمة مكافحة غسل الأموال المطبقة في المصرف ومدى التزام العاملين بهذه الأنظمة. 9. الدور الذي يلعبه مجلس إدارة المصرف في الرقابة على أنظمة مكافحة غسل الأموال ومعالجة ما بها من أوجه قصور. [27]

خامساً: إجراعات إدارة الامتثال في مكافحة غسل الأموال. هنالك جملة من الإجراءات التي يتعين على مراقب الامتثال أن يتبعها في مجال مكافحة غسل الأموال لضمان الحفاظ على سلامة وسمعة المصرف من المخاطر التي قد يتعرض لها في حالة حصول حالات غسل أموال أو عدم الالتزام بالتعليمات و القو انين، [14] و أهمها: [41] 1. أن يقوم بفحص كافة الحالات التي يشتبه بها. 2. أن يعد تقرير بحالات الاشتباه ويقوم بتوجيه إلى وحدة التحريات. 3. تحديث الإجراءات طبقا للتعليمات المحلية والدولية في هذا الثأن. 4. تدريب العاملين على وسائل مكافحة غسل الأموال. 5. الاحتفــاظ بالمستـندات الخاصـة بالحـالات المشـتبه بهـا. [33]

6. إعداد تقرير دوري عن نشاط مكافحة غسل الأموال بالمصرف يتم عرضه على مجلس الإدارة ويراعي أن بتضمن التقرير العديد من الامور أهمها: [14] 
أــ التي تمت على الضو ابط الرقابية أو القوانين أو النظم الداخلية بالمصرف في مجال مكافحة غسل الأموال خلال الفترة المعد فيها التقرير بالإضافة إلى أي اقتر احات بشأن إجر اء التعديلات بالنظم الداخلية المطبقة بالمصرف في هذا الثأن. بـ الإشر اف العام على التز ام جميع فروع المصرف بتطبيق أحكام الضو ابط الرقابية و القو انين و النظم الداخلية بالمصرف في شأن مكافحة غسل الأموال. التأكد من أن جميع إجراءات إعرف زبونك يتم تتفيذها بشكل كامل وسليم بكل الفروع وتعديل الإجراءات والنماذج

$$
\text { المستخدمة لكي تتواءم مع مبدأ إعرف زبونك كلما كان ذلك ضروريا. }
$$

د- أن يقوم بزيارات ميدانية إلى الفروع لتقييم مدى دراية الموظفين بالضوابط الرقابية والقوانين والنظم الداخلية في المصرف بشأن مكافحة غسل الأموال. كما أن هناك إجراءات أخرى على مر اقب الامتثال أن يلجأ إليها بالمشاركة مع مسؤول وحدة غسل الأموال في المصرف أو لوحده في حالة عدم وجود تللك الوحدة وهي: [40]

1. مر اقبة ومتابعة العمليات المصرفية المالية من أجل كثف الأنشطة التي من الممكن أن تتضمن عمليات غسل للأمو ال. 2. تلقي البلاغات من الفروع والإدارات الداخلية المختلفة في المصرف عن العمليات المشتبه أنها تضم غسل أموال أو لدى محل الصر افة مما يتطلب توفر المعلومات وتحليل نتائجها واتخاذ القرار اللازم لتنفيذ الاجراء المناسب وتوثيقه كتابياً. 3. القيام بعملية إبلاغ المعلومات إلى وحدة التحريات في المصرف وإرسال نسخة منه إلى البنك المركزي حال تحديد الاشتباه، وذلك وفقا لإجراءات التبليغ المستخدمة مع إعداد تقرير فني شامل عن الحالية المشتبه بها خلال المدة المحدة نظامياً للإبِلاغ. 4. تطوير بر امج آلية لمر اقبة أنشطة غسل الأموال وتحديث المؤشرات التي تبين وجود أعمال مشتبه بها مثل غسل الأموال على نحو مر افق تطور وتنوع التقنيات المستخدمة في ارتكاب الجر ائم المالية. 5. تقديم بعض المقترحات الهادفة إلى تطوير السياسات والإجراءات والضوابط الداخلية ووضع المناهج لتسهيل تتفيذ هذه المقترحات و المو افقة على إنشاء برنامج آلي حديث ومتطور في مجال مكافحة غسل الأموال. 6. التأكد من أن العاملين في الفروع والإدارات الأخرى ملتزمين بالتعليمات والإجراءات المتعلقة بمر اقب الحسابات وأنهم يعلمون أهمية التعليمات و الإجر اءات المرتبطة لمكافحة الأنشطة المشتبه وتلبية منطلبات الإبلاغ. [40] 7. دعم إدارة الامتثال في التحقق من استخدام القو اعد والتنظيمات و المنطلبات الموضو عة بشكل سليم وفقاً لمنطلبات مكافحة 
8. إنتقاء العاملين المؤهلين لشغل المناصب في قسم ووحدة وتطوير مواد التنريب والاستمرار في تعليمهم لتزويدهم بآخر المعلومات المتعلقة بأنشطة غسل الأموال من أجل تحسين معرفتهم في توصيف هذه الأنشطة و أنماطها وطبيعتها وكيفية

$$
\text { التخلص منها ومعالجتها. }
$$

9. إعداد التقارير الدورية عن الأنشطة التي يمارسها قسم مر اقبة غسل الأموال/ مسؤول قسم الامتثال المعين لمكافحة أنشطة غسل الأموال وعن الوضع العام للمصرف أو محل الصر افة وإدارته وفروعه المختلفة، كما يلزم دعم هذه التقارير بالبيانات الاحصائية عن هذه الأنشطة وبالتوصيات الصادرة لتحسينها وتطوير ها. 10-الالتزام التام بجميع التعاميم والطلبات التي تصدر عن البنك المركزي بخصوص كشوفات حسابات الزبائن وتجميدها وتوفير المعلومات المطلوبة بالطريقة المناسبة وضمن الإطار الزمني الملائم. 11- يجب أن يحتفظ بقاعدة البيانات التي تتضمن كافة العمليات المتخصصة بمسائل غسل الأموال في المصرف أو محل الصر افة مثل حالات المشتبه بها التي تم الإبلاغ عنها والحسابات المجمدة وغير ها، إضافة إلى تحديث مجمل الحالات السابقة في قاعدة البيانات.

و على صعيد تدقيق السجلات المحاسبية لدى المصرف فإن على مر اقب الامتثال أن ير اعي ما يلي: [14] 1) تدقيق الحسابات المفتوحة في كل فرع و التأكد من أن ملف الحسابات يحتوي على المعلومات الأساسية الخاصة بالزبون، فيجب أن يتضمن الملف الخاص بالزبون (الفرد) ما يثبت هويته وعنو انه الكامل ورقم هاتفه ونوع عمله، وبالنسبة للزبون إذا كان شركة فيجب أن يحتوي الملف على النظام الأساسي الخاص بها، السجل التجاري، العنوان الكامل، طبيعة العمل، الميز انية العمومية والبيانات المالية، معلومات عن أصحاب الشركة الظاهرين وذوي الحق الاقتصادي إضافة إلى رئيس مجلس الإدارة والمدير التنفيذي. 2) تدقيق يومي لجدول العمليات النقدية والتأكد من عدم وجود مبالغ مشكوك بمصدر ها، وفي حالة وجود شك يرفع تقرير إلى مدير العمليات في الإدارة العامة للنظر بالموضوع. 3) في حالة استلام مبالغ مشكوك فيها خلال دوام العمل عليه نبليغ مدير العمليات فورا أو من ينوب عنه في الإدارة العامة لاتخاذ القرار المناسب.

\section{سادساً: واجبات مراقب الامتثال في مكافحة غسل الأموال.}

ومن بين أهم واجبات مراقب الامتنال هو الالتزام بالقو انين والتحقق من مدى الالنزام بها، والتشريعات المتعلقة بغسل الأمو ال لغرض الحد منها ومكافحتها، إذ قضت المادة (5/20) من دليل الحوكمة لسنة 2018 الصادر عن البنك المركزي العر اقي بأن تقوم إدارة قسم الامتثال بإعداد سياسات وإجر اءات فعالة لضمان مدى امتثال المصرف بتلك التشريعات و التعليمات 
النافذة جميعها وأية إرشادات وأدلة ذات علاقة، وعلى المصرف نوثيق صلاحيات ومهام مسؤوليات إدارة الامتثال، ويتم إعمامها داخل المصرف. ويلحظ من هذا الثأن أن الكثير من المعايير والتشريعات والأدلة الصادرة قد نركت أثراً مهما لمر اقب الامتثال في مكافحة غسل الأموال ومن أهمها: - 2

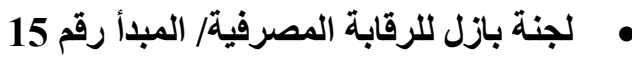

أنشارت اللائحة التنظيمية رقم (2) لسنة 2007 الصادرة من قبل البنك المركزي العراقي إلى المبدأ الــ(15) من المبادئ الأساسية للرقابة المصرفية الفعًالة الصادرة من لجنة بازل، ومعايير تطبيقه المتعلقة بمكافحة غسل الأموال الذي تضمن

1. على مر اقب الامتثال أن يتأكد من أن لاى المصرف سياسات، و إجراءات فاعلة تدعم المعابير الأخلاقية، والمهنية، تحول دون استغلال المصرف من العناصر المجرمة عن قصد، أو غير قصد وكثف النشاط الإجرامي وإبلاغ السلطات المسؤولة عن أي نشاط مشبوه. 2. يتأكد مر اقب الامتثال من أن المصارف تقوم بتوثيق، وتنفيذ ساسة تحدد هوية العميل ومن ينوبون بالوكالة عنهم كجزء مهم من برامجها لمكافحة غسل الأموال، إذ هناك قو اعد معلنة وو اضحة بشأن السجلات التي يجب أن تحتفظ بهوية العملاء، ومدة الاحتفاظ، و الصفقات الفردية.

3. التأكد من أن المصرف يمتلك إجراءات رسمية لرصد التعاملات التي من الممكن أن تحتوي الثبهة المحتملة، تشمل هذه الإجراءات تفويض، وفحص إضافي من المسؤول لبعض عمليات السحب أو الايداع مبالغ ضخمة من النقد وإجراءات خاصة للعمليات غير الطبيعية. كذللك على المر اقب أن يتأكد من وجود إجر اءات واضحة ومبلغة إلى العاملين ليقوموا بالإعلام عن أية عمليات غير عادية .4 إلى المسؤول الأعلى و الذي يشرف على التقيد بمكافحة غسل الأمو ال. 5. يتأكد مر اقب الامتثال عن طريق الفحص المسنمر لضو ابط غسل الأموال لدى المصرف، و أنظمته لمنع العمليات المشبو هة ورصدها والإبلاغ عنها ويكون لمر اقب الامنتال سلطات تنفيذية كافية لاتخاذ أية إجراءات ضد المصرف الذي لا يتقيد بالتز امات مكافحة غسل الأمو ال. 6. على مر اقب الامتثال أن يتأكد من أن المصرف قد وظّف مسؤو لاً يمتلك مسؤولية و اضحة للتأكد من أن سياسات المصرف، و إجر اءاته تتو افق كد أدنى مع الثروط التنظيمية و التشريعية لمكافحة غسل الأمو ال. 


\section{ولغرض تطبيق ما تقلم فإن ذلك يستلزم ما يأتي: [14]}

1) على مراقب الامتثال في المصرف أن يعمل على تقديم ما يراه مناسبا إلى إدارة المصرف بضرورة وجود إجراءات

$$
\text { رسمية لكثف وضبط التعاملات التي تقع تحت دائرة الاشتباه. }
$$

2) التحقق من صحة إجراءات أقسام المصرف بشأن نوثيق السجلات، وتطبيق مبدأ إعرف زبونك (KYC)، والملحوظة المستمرة لموظفي المصرف للتأكد من مدى تطبيقهم لمبدأ إعرف زبونك على وفق الصلاحية المناط بها.

3) التوجيه المستمر لموظفي المصرف وخاصة موظفي الحسابات الجارية والحوالات، وقسم غسل الأموال بضرورة التبليغ غن أية حالة اشتباه، وبسرية تامة، وبذلك يتم زرع الاطمئنان عن موظفي المصرف فيما يخص الإبلاغ. 4) على مر اقب الامتثال أن يقوم بتقييم الضو ابط التي وضعها المصرف لمكافحة غسل الأموال، و اقتر اح التعديلات إن لزم. 5) أن تتو افر لمر اقب الامتثال سلطات تنفيذية كافية، لاتخاذ أي تدبير ضد المصرف في حالة عدم تقيده بإجراءات مكافحة

$$
\text { غسل الأمو ال. [21] }
$$

\section{دليل الحوكمة المؤسسية للمصارف لسنة 2018.}

أشتار دليل الحوكمة المؤسية للمصارف في المادة (1/21) على مجلس الإدارة في المصرف، وعن طريق لجنة التدقيق و الإدارات أو الاقسام الرقابية للمصرف التأكد من اتخاذ المصرف تدابير العناية الواجبة تجاه العملاء على وفق "قانون مكافحة غسل الأموال وتمويل الإرهاب رقم 39 لسنة ،2015". حيث إن مر اقب الامتثال هو أحد الأقسام الرقابية في المصرف المعنية بذلك. كما نصت الفقرة (3) من المادة ذاتها على اعتماد بر امج خاصة لمنع غسل الأموال، منضمنة الآتي: [21] 1- - إجر اء تقييم لمخاطر غسل الأموال، التي هي عرضه لها.

2- الاعتماد على السياسات والإجر اءات و الضوابط الداخلية التي تليق بتطبيق الالتزامات المفروضة في مجال مكافحة غسل

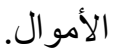
3- التدقيق المستقل لاختبار مدى الفاعلية للسياسات و الإجر اءات ومدى تطبيقها. 


\section{الاستنتاجات والتوصيات}

أولاً: الاستنتاجات

1- أصبحت وظيفة مراقب الامتثال المصرفي أحد الركائز في ممارسة النشاطات المصرفية، فهي تمثل حصانة المصرف من تعرضه للمخاطر والعقوبات وأهم هذه المخاطر هي عمليات غسل الأموال التي أخذت بالتوسع والانتشار في بلدان العالم، واتخذت من النظام المصرفي ملاذاً آمناً لتمرير الأموال غير المشروعة من قبل غاسلي الأموال لإضفاء الصفة المشروعة على أموالهم المتحصلة من الممارسات غير المشروعة كجريمة الإتجار بالمخدرات أو المتحصلة من العمليات الإرهابية. 2- إن لمراقب الامتثال دور في تحديد المخاطر وتقييمها ووضع وتنفيذ التدابير اللازمة لتخفيف وتقليل المخاطر ومتابعتها، و إعداد التقارير الخاصة بمخاطر عدم الامتثال وتقديمها إلى الإدارة العليا في المصرف. 3- الاهتمام الكبير لمر اقب الامتنال في التحقق من صحة الإجراءات التي يقوم بها المصرف بشأن استخدام استمارة إعرف زبونك (Know Your Customer) لما لها من أهمية كبيرة في بداية التعامل بين المصرف و العملاء مما يسهم في الحد من عمليات غسل الأموال في المصارف. 4- يرتبط مر اقب الامتثال بمجلس الإدارة مباشرة وفق الهيكل التنظيمي للمصرف، لذلك فأن استقلالية مر اقب الامتثال تقتضي عدم التأثير على سياقات عمله بحيث يجب أن تكون التقارير الصادرة إلى البنك المركزي أو مجلس الإدارة غير متأثرة بالضغوط و التنخلات. 5- إن إجر اءات مكافحة غسل الأموال تحمي النشاط المصرفي من المساءلة القانونية من قبل البنك المركزي أو مكافحة غسل الأمو ال، فالالتزام بالتعليمات و الأنظمة وتطبيق القوانين يحمي المصارف من مقاطعة البنك المركزي العر اقي، وبالتالي تحمي المصارف العاملة مصادر أمو الها بذريعة مكافحة غسل الأموال. 


\section{ثانياً: التوصيات}

1- على المصارف العر اقية الالنزام بتعليمات وقو انين البنك المركزي العراقي للرقابة و الإشراف على المصارف وذلك

لتوفير الحماية وتجنب المخالفات و المخاطر التي قد يتعرض لها القطاع المصرفي وخاصة مخاطر غسل الأمو ال. 2- تفعيل الإجر اءات والالتزامات المنصوص عليها في قانون مكافحة غسل الأموال ومراقبة مدى التزام المؤسسات

$$
\text { المالية بها و إصدار الإرشادات و التعليمات التي تشهل تتفيذ القانون. }
$$

3- تطوير وتتمية قسم إدارة الامتثال المصرفي، ضمن الهيكل التنظيمي للمصرف وأن يكون موظفيها من ذوي الخبرة

الكافية في جميع مجالات العمل المصرفي والإطلاع والتفهم المتكامل للقوانين والتعليمات التي يصدرها البنك

$$
\text { المركزي العراقي. }
$$

4- على المصرف وضع آلية مناسبة، ومشتركة بين قسم الإبلاغ عن غسل الأموال وقسم الامتثال المصرفي للتقصي عن

مصادر الأموال التي يشتبه بها، و إعطاء الصلاحية لمر اقب الامتثال للاشتراك مع بقية الجهات لوضع سياسات

$$
\text { وآليات في مجال مكافحة غسل الأمو ال. }
$$

5- أهمية قيام الجهات ذات العلاقة بتحديد الاطار العام المنظم لعمل مر اقبي الامتثال وتوصيف وظيفتهم بموضوعية وشمولية الهدف الأساسي لها للتأكد من امتثال المصارف طو عيا للقو انين و التعليمات الصادرة من البنك المركزي. 


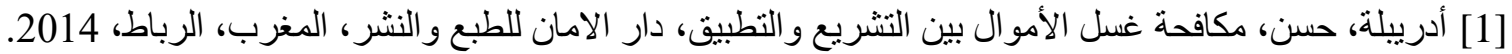
[2] البرزنجي، احمد محمد مهدي، سوق المال مدخل مالي/مصرفي، دار الدكتور للعلوم الادارية والاقتصادية، الطبعة الأولى، الطي،

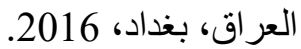
[3] الخريثة، امجد سعود قطيفان، جريمة غسل الأموال دراسة مقارنة، الطبعة الأولى، الثقافة للنشر والتوزيع، الاردن، عمان، 2006. [4] الخريشة، امجد سعود، جريمة غسيل الأموال دراسة مقارنة، الاردن، عمان، دار الثقافة للنشر والتوزيع، الطبعة الأولى،

[5] رمضان، محمد رمضان، نقل الأموال وتأمين البنوك، دار النهضة العربية للنشر والتوزيع، الطبعة الأولى، مصر،

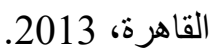

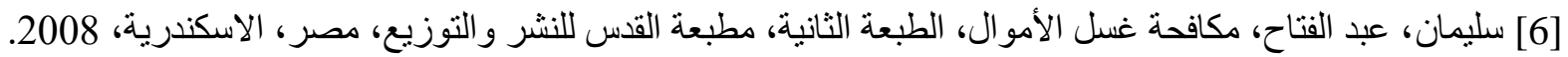

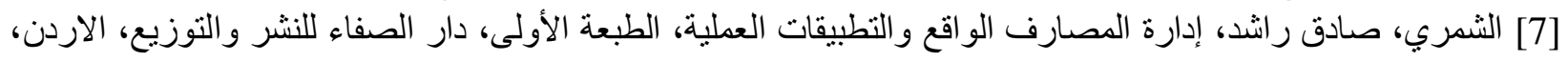
عمان، 2009.

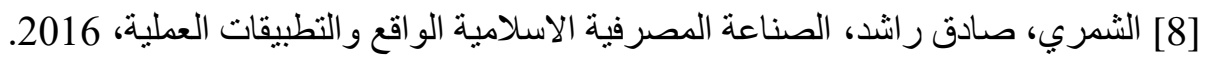

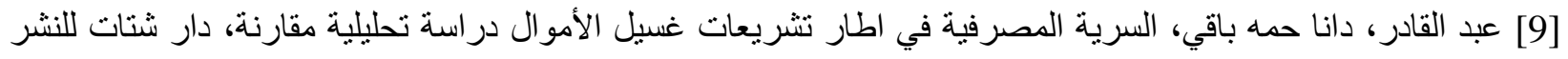

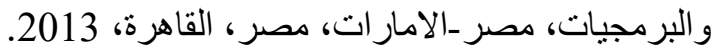

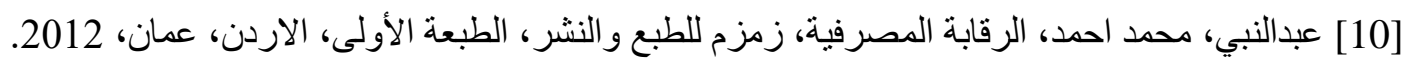

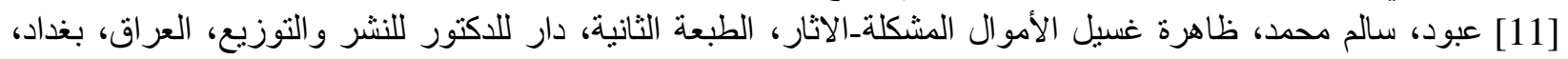
.2013 [12] القصير، يوسف عبدالله، مكافحة جريمة غسل الأموال دراسة تحليلية مقارنة، الدار العلمية الدولية للنشر و التوزيع،

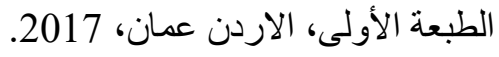

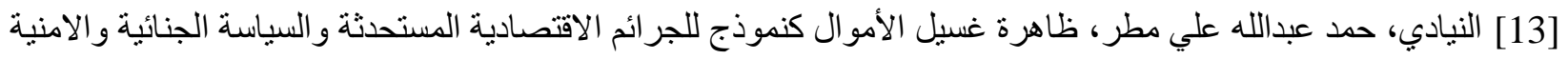

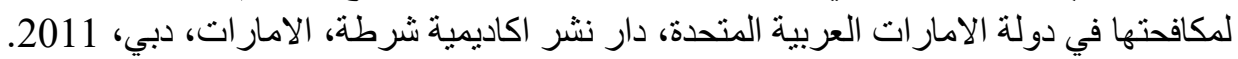

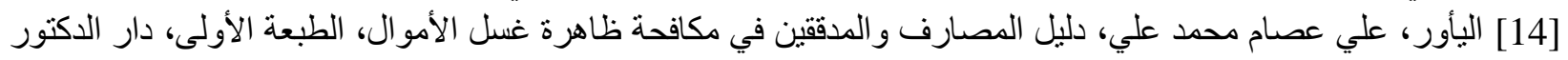

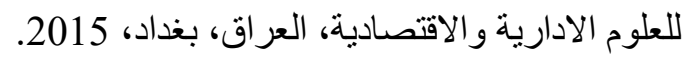

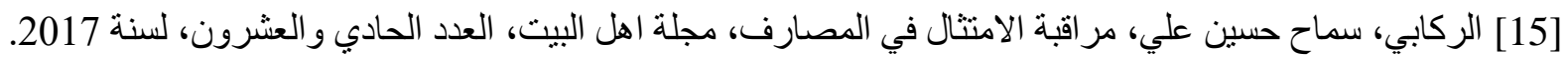

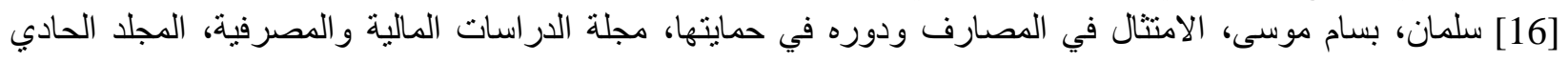

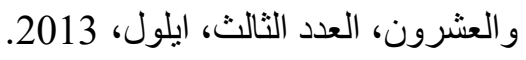
[17] العقدة، صالح خليل، الكخن، دلال خليل، مدى التزال التزام مدقق الحسابات الاردني في تدقيق برنامج مكافحة عمليات غسل

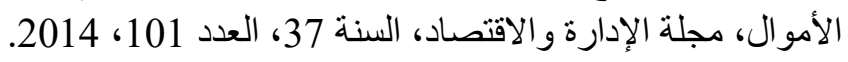

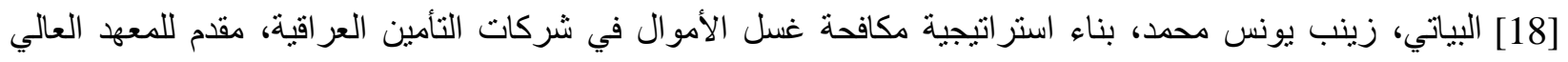

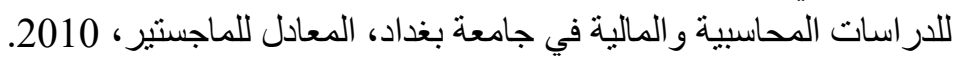

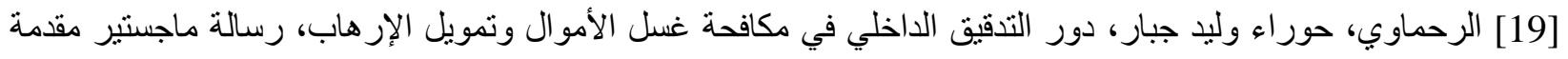

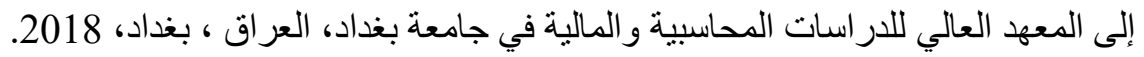

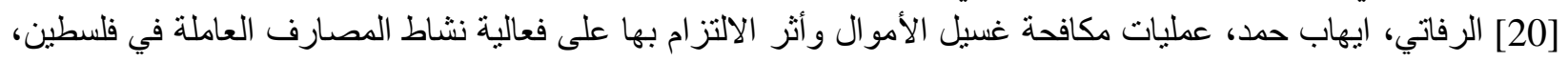

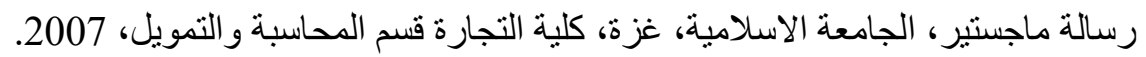

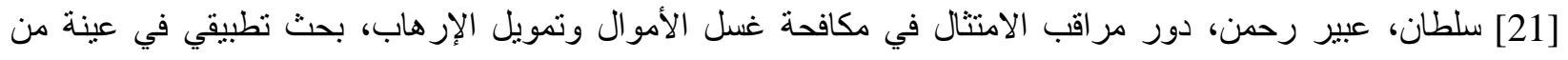

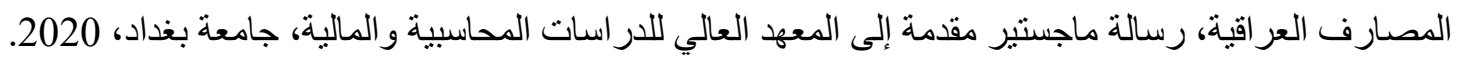

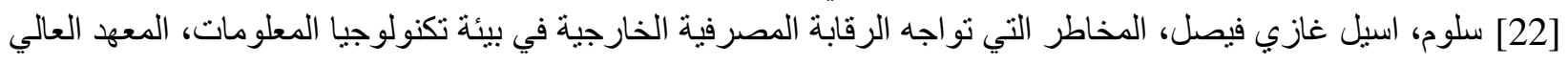

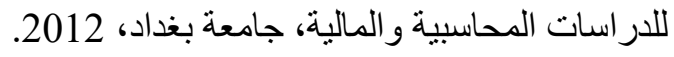
[23] علاوي، مهدي، وظيفة مر اقب الامنثال تعريفها وأهينها ومخاطر عدم الامتثال و أسبابه، مجلة دراسات مالية ومصرفية،

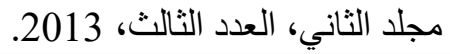


[24] العاجز، رنا فاروق، دور المصارف في الرقابة على عمليات غسيل الأمو ال دراسة تطبيقية على المصارف الفلسطينية

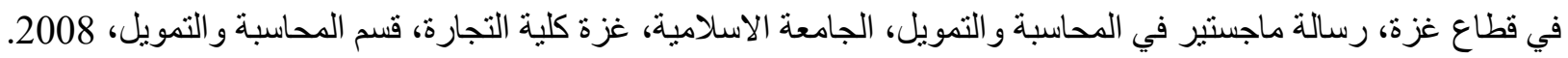
[25] العامري، حور اء احمد سلمان، دور التفتيش في تحقيق الامتثال المصرفي، رسالة ماجستير، المعهد العالي للاراسات

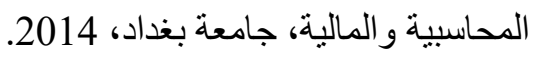

[26] العتبي، سعود ذياب، اثر السرية المصرفية على مكافحة جرائم غسل الأموال، رسالة ماجستير، جامعة نايف العربية

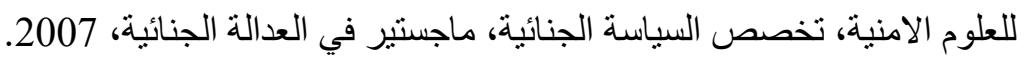
[27] علي، طيبة احمد، الرقابة المصرفية على عمليات غسل الأموال، رسالة ماجستير إلى كلية القانون جامعة بابل في القانون

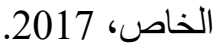
[28] غفوري، ساجدة غفوري علي، دور التدقيق الداخلي في الحد من جرائم غسل الأموال بحث تطبيقي في عينة من

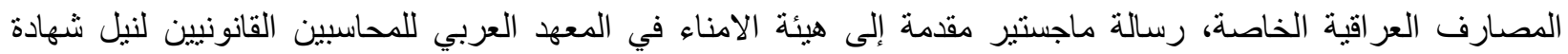
المحاسبة القانونية، العراق، بغداد، 2011. [29] كاظم، نبراس جاسم، مسؤولية الجهاز المصرفي العراقي في مكافحة غسل فئل الأموال دراسة تطبيقية في المصارف

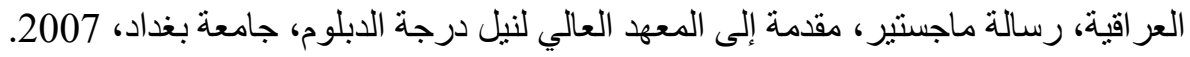

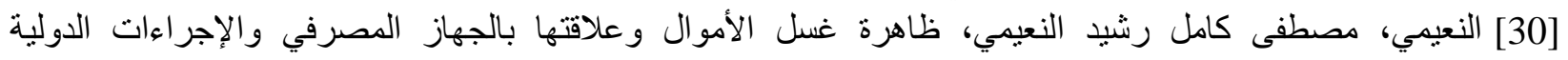

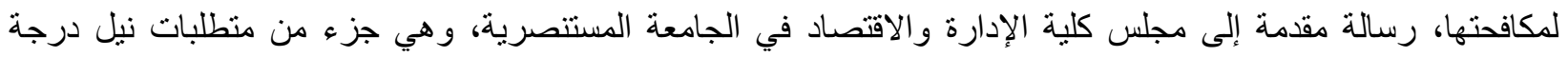
الماجستير في العلوم الاقتصادية، 2005.

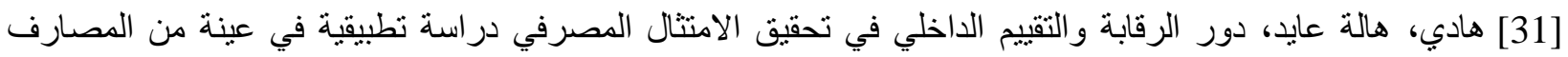

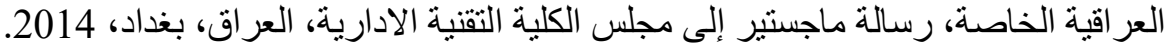

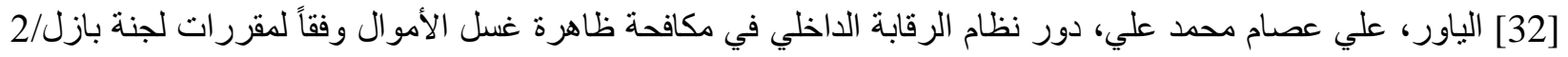

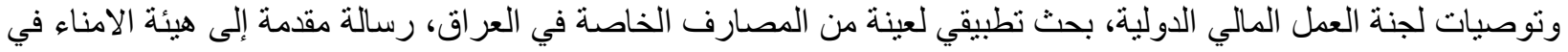

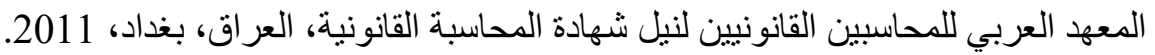

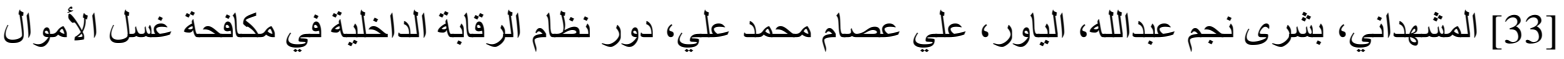

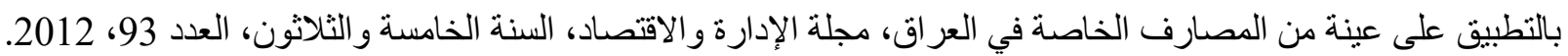

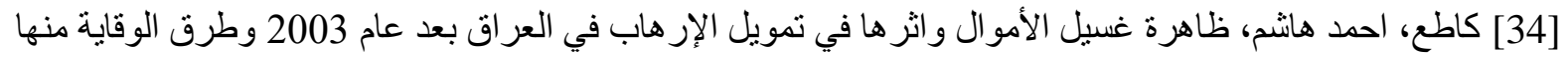

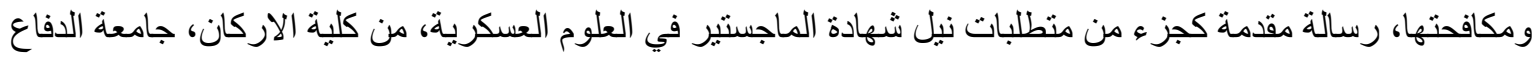

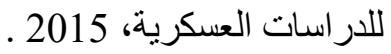

[35] Belavskis ، Guntis • Latvia Banking Developments and compliance status review،

Association of LATVIAN commercial banks ، 2017.

[36] Ergys Trana، The compliance function in banks and the need for Increasing and strengthing its Role-Lessons Learned from Practice، England، 2016.

[37] Michael Levi and peter reuter، Money Laundering the university of Chicago، 2006. USA.

[38] Aderonke، Alberta Tayo-Tiwo، Nigerian banks compliance with the code of corporate Governance، Walden University، college of management and Technology، 2018.

[39] Europe، Economics study on the cost of compliance with selected FSAP measures LONDON، 2009.

[40] Irfan‘ syed، Guidelines on compliance risk management state bank of PAKISTAN، banking policy and regulations Departmwnt، 2017.

[41] Monegram، Anti-Money laundering compliance Guide Latin America and the Caribbean، 2008.

[42] Billy Steel، money laundering • Brief history، 2006. Internet، http;//www.laundry maney.u-net.com. 
[43] Jennifer Hanley، many laundering typologies anti-money laundering regimes and the third EU directives approach to customer due diligence available attached pdf file on ، 2010، http://www.compliance in sider .com/feautures /money laundering visited on.

[44] Mc Cathy، 2011، Anti-Money Laundering association of chartered certified account ants، www.accagloba.com 